\title{
The Effect of Papaya (Carica papaya L.) Leaf Extract to the Number of Trypanosoma evansi Steel in Liver and Kidney of Mice (Mus musculus L. 1758)
}

\section{Yudi Yahya, Anni Nurliani, and Heri Budi Santoso}

Department of Biology, Faculty of Mathematics and Natural Sciences, Lambung Mangkurat University, Jl. A. Yani Km 35.8 Banjarbaru 70714, Indonesia

\section{Abstract}

The purpose of this study proved the activity of the ethanolic extract of papaya leaf as anti-trypanosomiasis agent, determined the dose of extract which having an effect in inhibiting growth of $T$. evansi, and evaluated the histopathology of liver and kidney infected by Trypanosoma evansi Steel. Male Balb-c mice were infected by $3 \times 10^{7} \mathrm{~T}$. evansi isolates. The native method was used to determine the level of parasitemia.The preparation was made using cytological smear method and paraffin method. The results showed that ethanolic extract of papaya leaf decreased the number of $T$. evansi. Ethanolic extract of papaya leaf at a dose of $300 \mathrm{mg} \cdot \mathrm{kg}^{-1} \mathrm{BW}$ is the most influential dose to reduce the number of $T$. evansi in liver and kidney of mice. Liver

Corresponding Author: Yudi Yahya yudiyahya@live.com

Received: 11 February 2017 Accepted: 08 March 2017

Published: 26 March 2017

Publishing services provided by Knowledge E

(a) Yudi Yahya et al. This article is distributed under the terms of the Creative Commons

Attribution License, which permits unrestricted use and redistribution provided that the original author and source are credited.

Selection and Peer-review under the responsibility of the ICBS Conference Committee.

\section{G OPEN ACCESS} reveals degenerative change varying such as congestion, lipid degeneration, vacuolar degeneration, necrosis, and cellular infiltration. Kidney reveals tubular degeneration, necrosis, cellular infiltration, and glomerulonephritis.

Keywords: Carica papaya L.; kidney; liver; mice; Trypanosoma evansi Steel.

\section{Introduction}

Surra (trypanosomiasis) is a disease caused by infection with the haemo-protozoan belonging to the genus Trypanosoma. Trypanosoma is a parasite on the circulatory system, tissue fluid, and it can infect cells. Surra is endemic in Southeast Asia, and it is prevalent in Indonesia. Trypanosoma evansi Steel has a wide host range such as goats, sheep, pigs, dogs, cats and other wild animals. The disease is the most important single cause of economic losses such as slack up livestock growth, decreased livestock production, morbidity, and mortality [1]. In addition, Mackenzie et al. [2] mentions that $T$. evansi infection can cause immunosuppression or reduced immune response of the host or also called a clinical allergy.

Surra has a negative impact on the population of buffalo in the Philippines. Growth of buffalo population in endemic areas lower 50\% compared with areas that are not. Economic losses due to this disease is estimated at up to 158 ooo USD per year [3]. In Indonesia, surra was reported by Direktorat Kesehatan Hewan [4] occurred on Sumba, 
East Nusa Tenggara in 2010 to 2011. The result showed that 4268 cattle was expressed trypanosomiasis while livestock deaths caused by this disease are reported as many as 1760 cattle [4].

Control of $T$. evansi has been done by giving the antitrypanosomal (Suramin), but it is reported to have occurred Trypanosoma resistance. Research in Balai Penelitian Veteriner showed almost all isolates of $T$. evansi in Balivet resistant to isometamidium and most of the isolates were resistant to diminazene aceturate [5]. Therefore, control of the disease depends on the ability of the new drug which have a role as new anti- $T$. evansi to anticipate Trypanosoma resistance to all drugs.

Carica papaya (L.), commonly known as papaya, is a fruit crop cultivated in tropical and subtropical regions, and well known for its nutritional benefits and medicinal applications. Jimenez-Coello et al. [6] have used papaya seed extract as antitrypanosomal agent [6]. Papaya leaf was utilized as antitrypanosomal still not have been done. Therefore, it is necessary to evaluate the effects of papaya leaf extract to the number of $T$. evansi in the liver and kidneys of mice infected by $T$. evansi and determine the histopathological effect.

\section{Materials and Methods}

\subsection{Processing of plant samples}

The leaves were washed, cut into small piece, and dried for five days. The samples were ground into powder and stored before use for analysis. Papaya leaves extracted by maceration method using ethanol $96 \%$. Extraction was done for $3 \times 24 \mathrm{~h}$. The solvent was evaporated using a rotary vacuum evaporator at temperatures up to $40^{\circ} \mathrm{C}$ until the solvent does not evaporate again [7].

\subsection{Phytochemicals analysis}

The analysis for alkaloids, flavonoids, saponins, tannins, and steroids was carried out according to standard methods [7].

\subsection{Study design}

This study is an experimental research using completely randomized design (CRD) with five treatment variables and five replications for each treatment. All mice were then divided randomly into five groups, each consisting of five mice with different treatment for each group, namely:

- Group Po (negative control) untreated infection $T$. evansi and ethanol extract of papaya.

- Group P1 infected by $T$. evansi, but not given the ethanol extract of papaya.

- Group P2 infected by $T$. evansi and ethanol extract of papaya $75 \mathrm{mg} \cdot \mathrm{kg}^{-1}$. 
- Group P3 infected by $T$. evansi and ethanol extract of papaya $150 \mathrm{mg} \cdot \mathrm{kg}^{-1}$.

- Group P4 infected by $T$. evansi and ethanol extract of papaya $300 \mathrm{mg} \cdot \mathrm{kg}^{-1}$.

\subsection{Trypanosoma evansi isolate}

T. evansi isolate used in the present study was obtained from Balai Veteriner Banjarbaru. Twenty-five Balb-C mice were infected with $T$. evansi by injecting with $0.2 \mathrm{~mL}, 3 \times$ $10^{7}$ parasites by intraperitoneal route. Tail clipping collected the blood of infected mice and daily examined beginning from the second-day post inoculation. Infected mice blood showing a high parasitaemia was collected directly from the heart. Determination of categories parasitaemia observed under a microscope with a magnification of $400 \times$ is classifying as absent $(-)$, slight $(+)$ ( 1 to 5 Trypanosomes/field), moderate $(++)$ (6 to 15 Trypanosomes/field), severe $(+++)$ (15 to 25 Trypanosomes/field), and very severe $(++++)$ (> 25 Trypanosomes/field).

\subsection{Animal treatment}

Extract administered orally as much as $0.3 \mathrm{~mL}$. The treatment is given to mice that have been categorized as having very severe parasitaemia by category $(+4)$ in the previous inspection using native methods. The treatment was done for three days. On $4 \mathrm{~d}$ after treatment, all of the mice were sacrificed to take the liver and kidneys.

\subsection{Cytological preparation}

Cytological preparations of liver and kidney were conducted using a smear method with Giemsa staining [8]. Observation was done with a magnification of 1000x. The average number of 10 field of view averaged to obtained the average number of $T$. evansi each mouse. The average number of $T$. evansi each mouse combined and averaged to obtained the average number of $T$. evansi each treatment group. The data obtained were processed with SPSS 20.0 for Windows and data distribution curve seen with the test One Sample Kolmogorov-Smirnov and Levene homogeneity test. If the observed data meet the requirements of parametric analysis, the data were analyzed using ANOVA (Analysis of Variance) and continued with Duncan test. If the observed data does not meet the requirements of parametric analysis, the data were analyzed using Kruskal-Wallis test followed by Mann-Whitney test. Significance level used was $\alpha=0.05$.

\subsection{Histological preparation}

Small pieces of tissue samples were collected in 10\% formalin. Histological preparations of liver and kidney were conducted using a paraffin method [9]. Thin sections of 5 $\mu \mathrm{m}$ thickness were cut and stained with routine haematoxylin and eosin (HE) staining for recording the histopathological change. Qualitative observations were conducted 


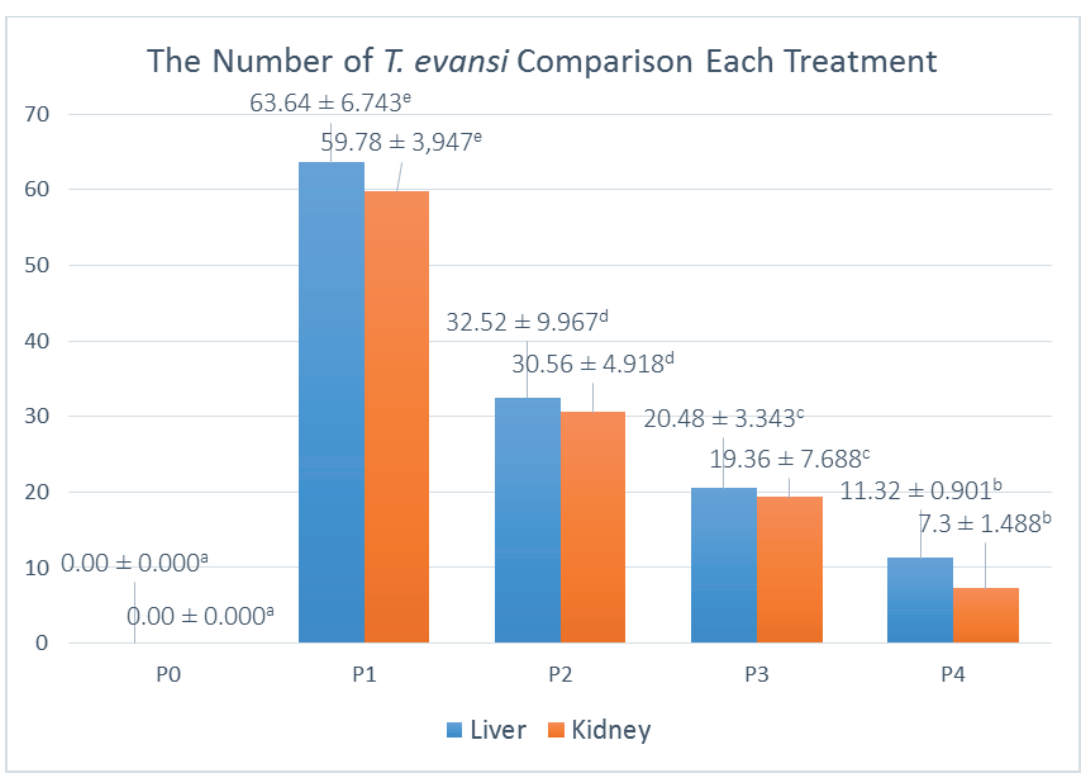

Figure 1: Diagram of the number of $T$. evansi comparison each treatment.

to the liver, including congestion, necrosis, fatty degeneration, and vacuolar degeneration. While the kidney was observed for tubular degeneration, necrosis, cellular infiltration, and glomerulonephritis [10].

\section{Result and Discussion}

The mean, standard deviation and the significance of the number of $T$. evansi in the liver and kidneys of mice after treated with ethanol extract of papaya leaf on each treatment are presented in diagram form in Figure 1. The ethanol extract of papaya leaves decreased the number of $T$. evansi both the liver and kidneys. Number of $T$. evansi in the $\mathrm{P}_{1}$ group is the largest number as compared to other treatment groups while the $\mathrm{P} 4$ group had the least number of $T$. evansi compared with the other treatment groups ( $P_{1}, P_{2}$, and $\left.P_{3}\right)$ (see Figure 1 ).

Trypanosoma evansi infected mice intraperitoneally into the body and found in the blood. It is due to $T$. evansi able to penetrate the mucosal tissue in the internal organs and through a vein to the heart [11]. The heart pumps the blood which is infected by $T$. evansi to all organs of the body. It is evidenced by the existence of $T$. evansi in the liver (see Figure 2 ) and kidneys (see Figure 3 ) of mice. The growth of $T$. evansi increased after it infected to the mice (Mus musculus L.). However, the number of $T$. evansi decreased along with increasing doses of papaya leaf extract.

Analysis of the number of $T$. evansi in the liver of mice with Kruskal-Wallis and MannWhitney prove the effects of ethanol extract of papaya leaf against the number of $T$. evansi in the liver of mice. Results of the analysis of the number of $T$. evansi in the kidneys of mice with ANOVA and Duncan also prove the effect of ethanol extract of 


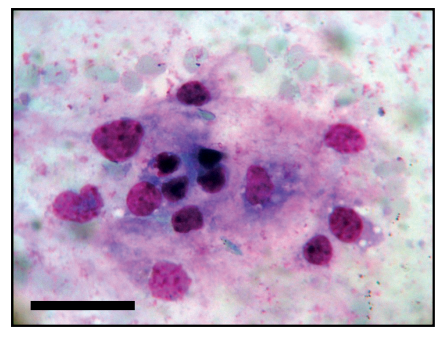

(a)

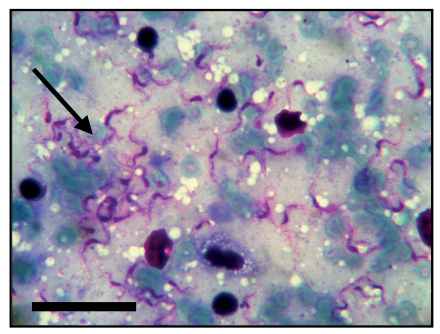

(b)

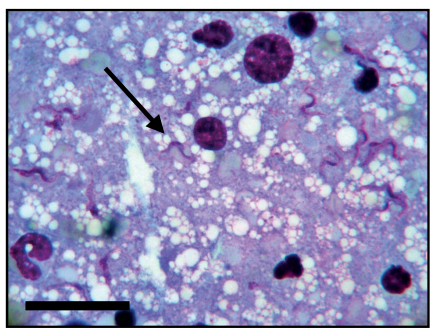

(c)

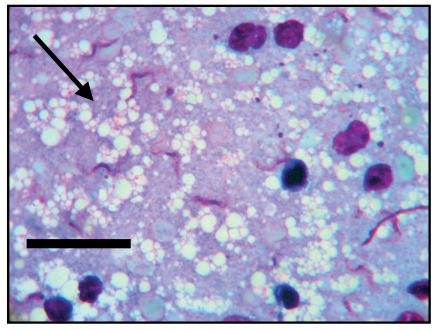

(d)

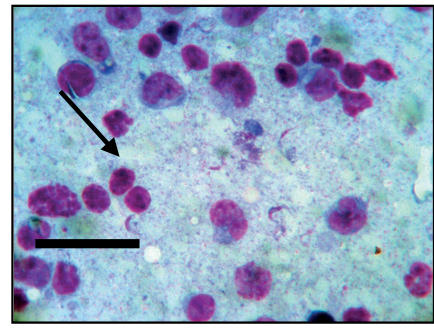

(e)

Figure 2: (a) Hepatic smear of negative control; (b) Hepatic smear of mice was infected by $T$. evansi; (c) Hepatic smear of mice was infected by $T$. evansi and ethanol extract of papaya $75 \mathrm{mg} \cdot \mathrm{kg}^{-1}$; (d) Hepatic smear of mice was infected by $T$. evansi and ethanol extract of papaya $150 \mathrm{mg} \cdot \mathrm{kg}^{-1}$. (e) Hepatic smear of mice was infected by $T$. evansi and ethanol extract of papaya $300 \mathrm{mg} \cdot \mathrm{kg}^{-1}$. ( $\left.\rightarrow\right) T$. evansi; scale $30 \mu \mathrm{m}$; Giemsa staining; magnification $1300 \times$.

papaya leaf against the number of $T$. evansi in the kidneys of mice. Number of $T$. evansi in the $P_{1}$ group has a significant difference to the other treatment groups for $P_{1}$ group only infected by $T$. evansi without being given papaya extract. There are caused by T. evansi grown rapidly without any factors which inhibited it. The body of the mice produced antibodies to fight invaders, but it is not capable of inhibiting the growth of $T$. evansi which had grown a lot. When compared with $\mathrm{P}_{1}$ group, $\mathrm{P}_{2}$ and $\mathrm{P}_{3}$ groups have a significant difference. This shows that doses of $75 \mathrm{mg} \cdot \mathrm{kg}^{-1}$ and $150 \mathrm{mg} \cdot \mathrm{kg}^{-1}$ decreased the number of $T$. evansi, but not yet approaching normal conditions. The P4 group had significant differences in all treatments including Po group (negative control). The average score of the number of $T$. evansi at $\mathrm{P}_{4}$ group had the least number of $T$. evansi compared with $\mathrm{P}_{2}$ and $\mathrm{P}_{3}$. This shows that the ethanol extract of papaya dose of $300 \mathrm{mg} / \mathrm{kg}$ was able to decrease the number of $T$. evansi, but still not approaching normal conditions.

Based on the Figure 1, the number of $T$. evansi at liver a bit more than the number of T. evansi in the kidneys in each treatment group. This is thought to be caused by blood flow to the heart more than the blood flow to the kidneys. $T$. evansi is flagellates that live in the bloodstream. According to Pearce [12], liver received blood from the artery hepatica that carries oxygen-rich blood from the lungs, and the portal vein carries nutrient-rich blood to the hepatocytes. While the kidneys receive blood only from the renal artery [12].

Papaya leaves contain secondary metabolites that are thought to contribute inhibiting the growth of $T$. evansi. According to Verpoorte and Alfermann [13], secondary metabolites are the metabolites that are not essential for the growth of organisms, 


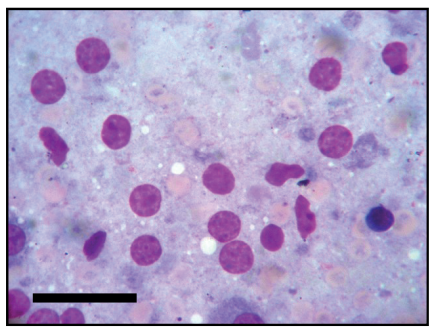

(a)

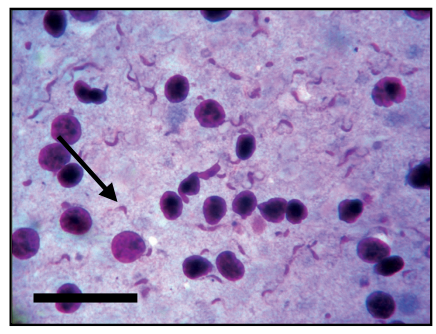

(b)

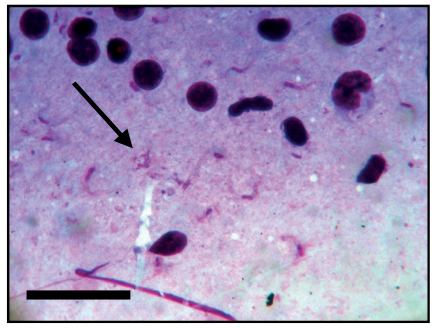

(c)

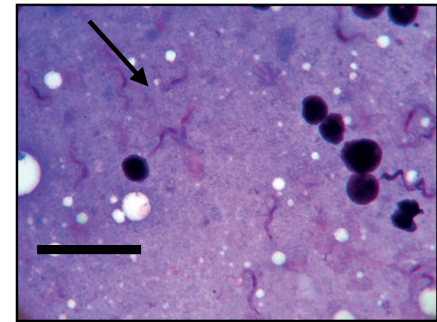

(d)

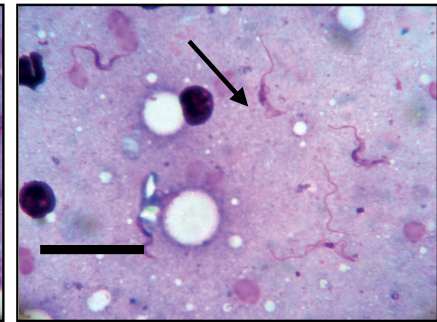

(e)

Figure 3: (a) Renal smear of negative control; (b) Renal smear of mice was infected by T. evansi; (c) Renal smear of mice was infected by $T$. evansi and ethanol extract of papaya $75 \mathrm{mg} \cdot \mathrm{kg}^{-1}$; (d) Renal smear of mice was infected by $T$. evansi and ethanol extract of papaya $150 \mathrm{mg} \cdot \mathrm{kg}^{-1}$; (e) Renal smear of mice was infected by $T$. evansi and ethanol extract of papaya $300 \mathrm{mg} \cdot \mathrm{kg}^{-1} ;(\rightarrow) T$. evansi; scale $30 \mu \mathrm{m}$; Giemsa staining; magnification $1300 \times$.

\begin{tabular}{l|c|c} 
Constituents & $\begin{array}{c}\text { Reagent } \\
\text { Alkaloid }\end{array}$ & Result \\
& Meyner & + \\
& Dragendorf & + \\
& $\mathrm{HCl}+\mathrm{Mg}$ & + \\
\hline Flavonoid & $\mathrm{H}_{2} \mathrm{O}$ & + \\
\hline Saponin & $\mathrm{FeCl}_{3}$ & + \\
\hline Tanin & $\left.\mathrm{CH}_{3} \mathrm{CO}\right)_{2} \mathrm{O}+\mathrm{H}_{2} \mathrm{SO}_{4}$ & + \\
\hline Steroid & $\left(\mathrm{CH}^{2}\right.$ &
\end{tabular}

TABLE 1: Phytochemical analysis.

and it is found in the unique structure between species and serves to defend themselves from unfavorable environmental conditions. Papaya leaves contain alkaloids, flavonoids [14], saponins [15], tannins [16], and steroids. This is evident after phytochemical test of the ethanol extract of papaya as shown in Table 1.

Alkaloids could inhibit the growth of $T$. cruzi in epimastigote phase [17]. Alkaloid has trypanocidal activity which causes a partial lysis in trypomastigotes phase. This is supported by Cowan [18] which states that carpain (alkaloid contained in papaya) has antiprotozoal effect. Flavonoids used to treat diseases caused by protozoa [19]. Flavonoids containing hydroxyl groups that influence the degree of oxygenation that may indirectly increase antiprotozoal activity through the inhibition of respiration [20]. The substances contained in plants, especially flavonoids have antitrypanosomal activity [21, 22]. Derivatives flavonoids expressed can suppress the growth of $T$. cruzi significantly [23]. 


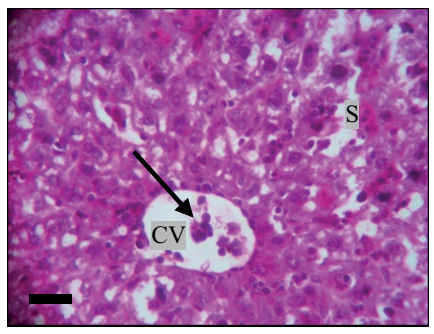

(a)

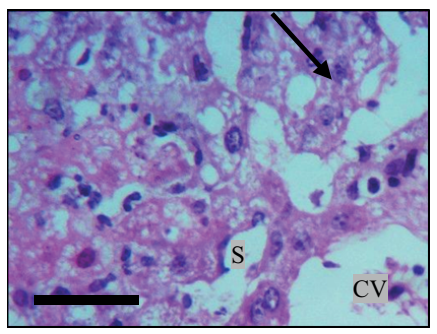

(b)

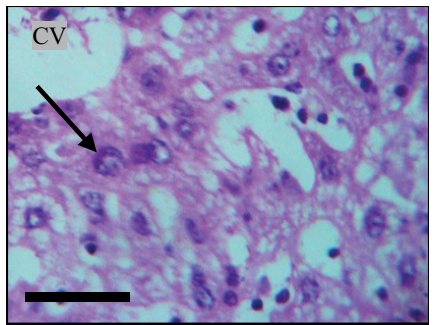

(c)

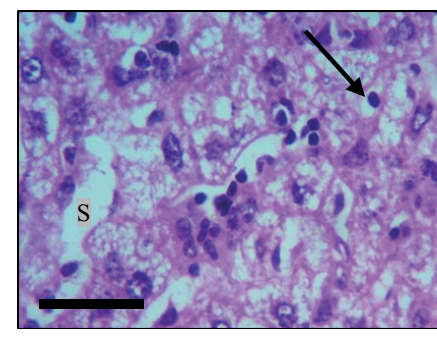

(d)

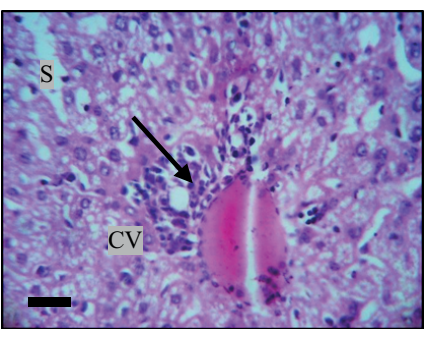

(e)

Figure 4: Histopathological of Liver (a) Congestion (520x); (b) Fatty degeneration (1 300x); (c) Vacuolar degeneration (1300X); (d) Necrosis (1300X); (e) Cellular infiltration (520X); S = sinusoid; CV = central vein; thickness $5 \mu \mathrm{m}$; scale $30 \mu \mathrm{m}$; HE staining.

Saponin has able to decreased the number of protozoa [24] and reacted with cholesterol in the cell membrane of protozoa that cause cell rupture and lysis [25]. This could lead to disruption of metabolic processes and inhibits the growth of protozoa. Saponins are glycosides that have the aglycone a steroid. Saponins and steroids disrupted the ion balance of microorganisms through inhibition of the $\mathrm{Na}+$ pump. Saponins stimulate specific antigen DTH (Delayed Type Hypersensitivity) and proliferation of T cells that play a role in cellular immunity [26]. It is also supported by Talib et al. [27] research reported that saponins from Sapindus rarak DC. seed methanol extract reduced $57 \%$ of protozoa. Saponins decreased the index number of $T$. cruzi and enhanced survival in mice given saponin [28]. The presence of tannins in the body of organisms are increased stimulation of phagocytic cells and anti-infection activity [18]. Tannins could disable an enzyme that works inside the body of $T$. evansi and disrupts the process of protein transport through the cell membrane, preventing the activity of protease and inhibit growth. Adelodun et al. [29] proved that the tannin contained in Uvaria chamae P.Beauv. capable of extending the long life of mice infected by $T$. brucei as well as reduce the level of parasitaemia.

$T$. evansi need glucose and oxygen for growth and development that lead to degenerative changes which disrupted the host body's metabolic processes. It can cause cell damage due the toxins produced by $T$. evansi or immune reaction. Degenerative change in liver due to infection of $T$. evansi may include congestion, fatty degeneration, vacuolar degeneration, and necrosis, while degenerative change on kidneys such as glomerulonephritis, necrosis, cellular infiltration and tubular degeneration [10].

Congestion, fatty degeneration, vacuolar degeneration, necrosis and cellular infiltration is the degenerative change found in the liver (see Figure 4). In the treatment P1 group (positive control) was found all kinds of cell damage. This condition is thought to be caused by the inability of the immune system to inhibit the activity of $T$. evansi 


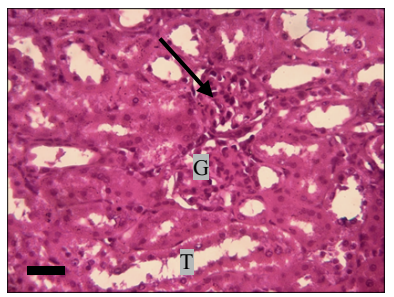

(a)

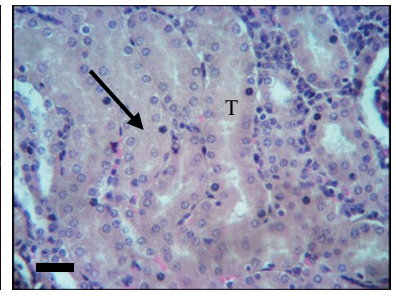

(b)

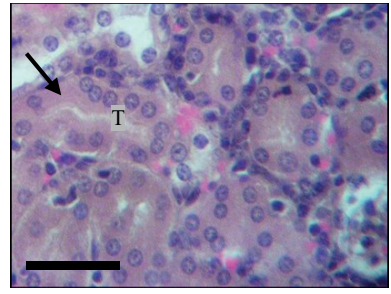

(c)

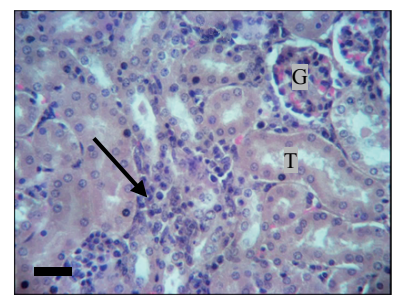

(d)

Figure 5: Histopathological of Kidney (a) Glomerulonephritis (520x; (b) Tubular degeneration (520x); (c) Necrosis (1 300X); (d) Cellular infiltration (520X); G = glomerulus; $\mathrm{T}=$ tubular; thickness $5 \mu \mathrm{m}$; scale 30 $\mu \mathrm{m}$; HE staining.

which takes up glucose and oxygen needed by hepatocytes. P2 group (dose of $75 \mathrm{mg}$. $\mathrm{kg}^{-1}$ ) still shows the same conditions as the $P_{1}$ group. While the $P_{3}$ group (a dose of 150 $\mathrm{mg} \cdot \mathrm{kg}^{-1}$ ), fatty degeneration was not found. This is probably caused by dosing extract more so inhibit infection of $T$. evansi and reversible nature of fatty degeneration, the cells will return to normal if the factors causing the damage is inhibited. In the $\mathrm{P}_{4}$ group (a dose of $300 \mathrm{mg} \cdot \mathrm{kg}^{-1}$ ), fatty degeneration and vacuolar degeneration was not found. This is probably because the dose of the extract that much more can inhibit the activity of $T$. evansi and the cells returned to normal.

Glomerulonephritis, tubular degeneration, necrosis and cellular infiltration were found in all treatment groups (see Figure 5). This means increasing doses of papaya leaf extract ethanol does not affect renal histopathology. However, it still needs further research to determine quantitative histopathological conditions due to infection with T. evansi and ethanol extract of papaya.

Trypanosoma evansi infections can cause degenerative change in the liver and kidneys. Administration of foreign substances in the body such as the papaya leaf extract can also provide known toxic effects to the tissue. However, the treatment group showed that papaya leaf extract led to a decrease in the ability and the inhibition of $T$. evansi to breeding, so that the number of parasites can be suppressed. Therefore, it is necessary to conduct further research on specific compounds that can suppress the growth of $T$. evansi and active the immune system to inhibit the activity of these parasites. The specific compound that is used is not expected to adversely affect to the tissues of the body so that it can restore the body back to normal. 


\section{Conclusion}

The ethanol extract of papaya had proven to decrease the number of Trypanosoma evansi in the liver and kidneys. The dose of $300 \mathrm{mg} \cdot \mathrm{kg}^{-1}$ of papaya leaf extract is the most able to decrease the number of $T$. evansi on the liver and kidneys than doses of $75 \mathrm{mg} \cdot \mathrm{kg}^{-1}$ and $150 \mathrm{mg} \cdot \mathrm{kg}^{-1}$. Liver revealed degenerative change varying such as congestion, fatty degeneration, vacuolar degeneration, necrosis and cellular infiltration. Kidney revealed glomerulonephritis, tubular degeneration, necrosis and cellular infiltration.

\section{Acknowledgements}

We gratefully acknowledge the support of the Department of Biology, Faculty of Mathematics and Natural Sciences, Lambung Mangkurat University. The authors would like to thank Balai Veteriner Banjarbaru, Indonesia, for providing the isolates and various facilities to carry out the research.

\section{References}

[1] AG. Luckins, "Epidemiology of surra: unanswered questions," J Protozool Res, pp. 106-119, 1998.

[2] A. R. MACKENZIE, P. R. SIBLEY, and B. P. WHITE, "Differential suppression of experimental allergic diseases in rats infected with trypanosomes," Parasite Immunology, vol. 1, no. 1, pp. 49-59, 1979.

[3] A. P. Dargantes, R. T. Mercado, R. J. Dobson, and S. A. Reid, "Estimating the impact of Trypanosoma evansi infection (surra) on buffalo population dynamics in southern Philippines using data from cross-sectional surveys," International Journal for Parasitology, vol. 39, no. 10, pp. 1109-1114, 2009.

[4] Hewan. Direktorat Kesehatan, Pedoman pengendalian dan pemberantasan penyakit Trypanosomiasis (surra) Guidelines for the control and eradication of diseases Trypanosomiasis (surra). Direktorat Jenderal Peternakan dan Kesehatan Hewan Kementrian Pertanian; 2012, p.1-3 in Bahasa Indonesia.

[5] IP. Sukanto, RC. Payne, and R. Graydon, "Trypanosomiasis di Madura. Survei parasitologik dan serologik[Parasitologik and serological survey]," Penyakit Hewan, vol. 19, no. 13, pp. 14-16, 1988, in Bahasa Indonesia.

[6] M. Jiménez-Coello, E. Guzman-Marín, A. Ortega-Pacheco, S. Perez-Gutiérrez, and K. Y. Acosta-Viana, "Assessment of the anti-protozoal activity of crude Carica papaya seed extract against Trypanosoma cruzi," Molecules, vol. 18, no. 10, pp. 12621-12632, 2013.

[7] JB. Harborne, Metode Fitokimia [Phytocemicals methods], Penerbit ITB, Bandung, 1987, 72 in Bahasa Indonesia.

[8] B. Stone and G. Reppas, "Cytology sample collection and preparation for veterinary practitioners., Murrarie," QML Pathology Vetnostics, pp. 1-8, 2010. 
[9] LG. Luna, Manual of histological staining method of the armed forces institute of pathology, McGraw-Hill, New York, 3rd edition, 1968.

[10] M. S. Bal, L. D. Singla, H. Kumar, A. Vasudev, K. Gupta, and P. D. Juyal, "Pathological studies on experimental Trypanosoma evansi infection in Swiss albino mice," Journal of Parasitic Diseases, vol. 36, no. 2, pp. 260-264, 2012.

[11] RUNW. Astuti, D. Rismawati, S. Hidayati, and SH. Suntoro, Pemanfaatan mindi (Melia azedarach L.) sebagai anti parasit Trypanosoma evansi dan dampaknya terhadap struktur jaringan hepar dan ginjal mencit Utilization mindi (Melia azedarach L.) as an anti-parasite Trypanosoma evansi and its impact on the network structure of the liver and kidneys of mice.. Kemajuan Terkini Penelitian Klaster Sains-Teknologi 2006; 291-309 in Bahasa Indonesia.

[12] EC. Pearce, "Anatomi dan fisiologi untuk paramedis [Anatomy and physiology for paramedics]," Gramedia Pustaka Utama, pp. 243-307, 2006, in Bahasa Indonesia.

[13] R. Verpoorte and AW. Alfermann, "Metabolic engineering of plant secondary metabolism," in Metabolic engineering of plant secondary metabolism, p. 29, Kluwer Academic Publishers, USA, 2000.

[14] SP. Fitrianingsih and A. Supriyatna Diantini, "A Muis. Aktivitas antiplasmodium ekstrak etanol beberapa tanaman obat terhadap mencit yang diinfeksi Plasmodium berghei [Activities antiplasmodium ethanol extract some medicinal plants to mice infected by Plasmodium berghei]," in Bandung, Prosiding SNaPP si Eksakto. LPPM UNISBA, vol. 13, p. 1, 2010 edition, 2010, in Bahasa Indonesia.

[15] PB. Ayoola and A. Adeyeye, "Phytochemical examination of the leaves of carica papaya L," Economic Botany, vol. 10, no. 3, pp. 256-260, 1956. 